\title{
Effect of intercropping carrots and onions on damage caused by the carrot fly, Psila rosae (F.) (Dipt., Psilidae)
}

\author{
ANNA-LIISA VARIS \\ Department of Agricultural and Forest Zoology, University of Helsinki, \\ SF-00710 Helsinki, Finland
}

\begin{abstract}
In small-scale field experiments carried out in southern Finland in seven successive years, rows of carrots were grown a) between carrot rows, b) between a carrot and an onion row, and c) between onion rows. The damage caused by the carrot fly, Psila rosae (F.) was slightly less in carrot rows adjacent to onion rows than in those adjacent to carrot rows. The infestation by the carrot fly was generally very low.
\end{abstract}

Index words: intercropping, Psila rosae, carrots, onions

\section{Introduction}

It is often claimed, especially in papers giving advice for horticulturists, that mixed cropping of carrots and onions can benefit carrots by reducing damage by the carrot fly (e.g. Philbrick and Gregg 1973). Heidema (1923) reported observations made by carrot growers that carrot flies can be controlled by growing onions among carrots. In the studies of Whitcomв (1938) and van Poeteren (1939), some protection against the carrot fly was to be seen in experiments in which onions were grown between carrot rows, while PETHERBRIDGE et al. (1942) found the damage in plots with alternate rows of onions and carrots very similar to that in plots with carrots alone. Uvah and CoAKer (1984) obtained a distinct reduction in the damage caused by the carrot fly by different row-intercropping arrangements of carrots and onions.

In recent times the increased efforts to use non-chemical methods in pest control have led to re-investigation of old practices. This paper describes the effect of row-intercropping carrots and onions on attacks by the carrot fly, Psila rosae (F.), in south Finland.

\section{Materials and methods}

Field experiments were carried out in 1976 -1982 at the experimental farm of the University of Helsinki, and in 1981 also at the experimental farm of Hankkija Plant Breeding Station in Tuusula near Helsinki (experi- 
ment 1981b). Carrots (cv. Feonia Fina Hunderup) and set onions (cv. Liva or Koma Stuttgarter Riesen) were grown in randomized blocks with five replicates. Each plot contained one test row $2 \mathrm{~m}$ long at a distance of $0.35 \mathrm{~m}$ from the adjacent rows. The onions were planted $10 \mathrm{~cm}$ apart, and the carrots thinned to $4 \mathrm{~cm}$ apart in the row. The test rows of carrots were situated a) between carrot rows, b) between a carrot and an onion row, and c) between onion rows. Guard rows of carrots were sown at each end of the experiment. The carrots were sown and the onions planted always on the same day in May, however, the date was not necessarily the same in different years.

The damage caused by the carrot fly was assessed immediately after the harvest in the beginning of September, by grading the roots according to the scale $0-5$ (fully healthy totally destroyed). $\mathrm{G}^{2}$-test with log-linear transformation was used for percentage data and the analysis of variance was used for mean damage. The analysis were also made with the pooled values of treatments b) and c).

\section{Results and discussion}

The carrot fly populations were very sparse except in the experiment 1981a. In the other experiments, the mean percentages of damaged plants in the treatments varied from 0 to 11.5 , the annual variation being significant $\left(\mathrm{G}^{2}=\right.$ 430.8 , df $=7, \mathrm{P}<0.01)$. In twelve cases out of sixteen there were fewer damaged plants in rows adjacent to onion than in those growing between carrot rows (Table 1) and the difference between these treatments was significant $\left(\mathrm{G}^{2}=5.19\right.$, df $\left.=1, \mathrm{P}<0.05\right)$ whereas the difference between single treatments without pooling $\left(\mathrm{G}^{2}=5.27\right.$, df $\left.=2, \mathrm{P}<0.10>0.05\right)$ was only indicative.

The mean degree of damage was very low (Table 1) varying between 0 and 0.13 (scale $0-5)$. However, it showed the same trend; there was only one case out of sixteen in which the degree of damage was higher in carrots adjacent to onions than in those growing between carrot rows.

There were no visual differences in the vigourness of the carrot and onion stands between different treatments and competition caused by row-intercropping was thus not apparent. In the experiments of UvaH and COAKER (1984), the frequency of damaged roots was considerably higher, and the effect of intercropping was also better. In the only case of the present study in which the dam-

Table 1. Damage caused by the carrot fly, Psila rosae (F.), in carrots grown between a) carrot rows, b) carrot and onion rows, c) onion rows.

\begin{tabular}{|c|c|c|c|c|c|c|c|c|c|c|c|}
\hline \multirow[t]{3}{*}{ Year } & \multicolumn{3}{|c|}{$\begin{array}{c}\text { Number of carrots } \\
\text { examined }\end{array}$} & \multicolumn{4}{|c|}{$\begin{array}{c}\text { Percentage } \\
\text { of damaged carrots }\end{array}$} & \multicolumn{4}{|c|}{$\begin{array}{l}\text { Mean damage } \\
\text { (scale } 0-5)\end{array}$} \\
\hline & \multirow[b]{2}{*}{ a } & \multirow[b]{2}{*}{ b } & \multirow[b]{2}{*}{ c } & \multirow[b]{2}{*}{ a } & \multirow[b]{2}{*}{ b } & \multirow[b]{2}{*}{$\mathrm{c}$} & \multirow{2}{*}{$\frac{b+c}{2}$} & \multirow[b]{2}{*}{ a } & \multirow[b]{2}{*}{ b } & \multirow[b]{2}{*}{ c } & \multirow{2}{*}{$\frac{b+c}{2}$} \\
\hline & & & & & & & & & & & \\
\hline 1976 & 358 & 280 & 296 & 5.7 & 2.0 & 2.2 & 2.1 & 0.06 & 0.03 & 0.02 & 0.02 \\
\hline 1977 & 284 & 280 & 262 & 2.2 & 1.6 & 1.9 & 1.8 & 0.02 & 0.02 & 0.02 & 0.02 \\
\hline 1978 & 311 & 244 & 229 & 0.3 & 0 & 0.4 & 0.2 & 0 & 0 & 0 & 0 \\
\hline 1979 & 190 & 190 & 169 & 7.0 & 4.0 & 5.9 & 5.0 & 0.07 & 0.05 & 0.07 & 0.06 \\
\hline 1980 & 156 & 114 & 178 & 0.8 & 2.5 & 0 & 1.3 & 0.03 & 0.02 & 0 & 0.01 \\
\hline $1981 a$ & 255 & 246 & 297 & 23.5 & 24.5 & 23.7 & 24.1 & 0.29 & 0.28 & 0.32 & 0.30 \\
\hline $1981 b$ & 229 & 243 & 257 & 6.8 & 4.9 & 4.9 & 4.9 & 0.08 & 0.05 & 0.05 & 0.05 \\
\hline 1982 & 179 & 185 & 178 & 11.5 & 5.3 & 7.4 & 6.4 & 0.13 & 0.07 & 0.12 & 0.10 \\
\hline \multirow[t]{2}{*}{ Mean } & & & & 7.2 & 5.6 & 5.8 & 5.7 & 0.08 & 0.06 & 0.08 & 0.07 \\
\hline & & & & & & & & & $\mathrm{F}$ & & \\
\hline Years & & & & & & & & & $16.18^{* * *}$ & & $38^{* * *}$ \\
\hline Treatments & & & & & & & & & 1.57 & & 68 \\
\hline Years $\times$ tr & ments & & & & & & & & 0.42 & & 28 \\
\hline
\end{tabular}


age caused by the carrot fly was considerable, there was no reduction in damage in the carrots adjacent to onions.

As the reduction of infestation by the carrot fly may depend on other features of the crop, such as plant density, age of the onions, and the pattern of mixed cropping (UvAH and COAKER 1984), the method could probably be improved to some extent. However, even at its best, this method does not seem to be feasible for more extensive plantings. In small domestic gardens, it could be of some help, and could perhaps be integrated with other methods of control, but even there protection of carrots against the carrot fly may be more easily achieved by covering the plots with sheets (see e.g. Häsel and KonRaD 1988), which would also give protection against other carrot pests.

Acknowledgement. The author is grateful to Mrs Silja Măkelä for technical assistance and to Dr Juha Helenius for statistical assistance.

\section{References}

HÃselı, A. \& Konrad, P. 1988. SchädlingsbefallRegulierung mit Netzen an Gemüse. Pfl.schutzber. 49: $1-8$,

Heidema, J. 1923. Voorkoming van de schade der made van de wortelvlieg aan gele en roode penen. Tijdschr. Pl.ziekten 29: 81.

Petherbridge, F.R., Wright, D.W. \& Davies, P.G. 1942. Investigations on the biology and control of the carrot fly (Psila rosae F.) Ann. Appl. Biol. 29: 380 -392 .

Philbrick, H. \& Grego, R.B. 1973. Companion plants $\&$ how to use them. Devin-Adair Company, Old Greenwich, Connecticut.

\section{SELOSTUS}

\section{Porkkanan ja sipulin sekaviljelyn vaikutus porkkanakärpäsen aiheuttamaan vioitukseen}

\author{
Anna-Liisa Varis \\ Helsingin yliopisto, \\ Maatalous- ja metsäelaintieteen laitos, \\ 00710 Helsinki
}

Porkkanan ja sipulin sekaviljelyn on usein varsinkin neuvonnallisissa kirjoituksissa sanottu văhentävän porkkanakärpäsen vioitusta. Asiaa selvittăviä tutkimuksia on văhän ja niissă saadut tulokset vaihtelevat. Joidenkin mukaan mitäăn tehoa ei ole havaittu, toisissa vioitusta on saatu văhenemăăn. van Poeteren, N. 1939. Verslag over werkzaamheden van den Plantenziektenkundigen Dienst in het jaar 1938. Versl. Pl. Ziekt. Dienst Wageningen no. 93. $92 \mathrm{p}$.

Uvah, I.I.I. \& COAKER, T.H. 1984. Effect of mixed cropping on some insect pests of carrots and onions. Ent. Exp. \& Appl. 36: 159-167.

Wнгтсомв, W.D. 1938. The carrot rust fly. Mass. Agric. Exp. Stat. Bull. no. 352.36 p.

Ms received March 22, 1991
Seitsemánă perăttäisenă vuotena Viikissă ja yhtenă vuotena Tuusulassa järjestetyissă kenttăkokeissa tutkittavat porkkanarivit sijoitettiin a) porkkanarivien văliin, b) porkkana- ja sipulirivin văliin ja c) sipulirivien văliin. Porkkanat kylvettiin ja sipulit istutettiin vuosittain samana päivănä, ja porkkanakărpäsen vioitus arvioitiin korjuun 
yhteydessä. Vioitus oli yleensä hyvin lievää. Porkkanakărpäsen aiheuttama vioitus oli hieman vähäisempäă sipuliin rajoittuvissa riveissä kuin porkkanarivien välisissă riveissă.

Eri tutkimuksissa saatujen tulosten erilaisuus voi ainakin osittain johtua erilaisista kasvustotekijöistä ja koejärjestelyistä, kuten kasvuston tiheydestä, sipulien kehitysasteesta, kummankin kasvilajin suhteellisesta osuudesta sekä kasvilajien keskinäisestä sijoituksesta kentälle. Näin ollen on ilmeistă, että menetelmäă voitaisiin jossain määrin kehittäă edelleen. Parhaimmillaankaan siitä ei kuitenkaan olisi suurten porkkanaviljelysten menetelmäksi. Kotipuutarhoissa sekaviljely voisi olla avuksi, ja sitä voitaisiin yhdistellä muihin torjuntamenetelmiin, mutta pieniltă alueilta porkkanakärpänen lienee helpommin torjuttavissa käyttämällä kateharsoa, joka samalla suojaa kasveja myös muilta tuholaisilta. 